\title{
Francisco de Vitoria and Alberico Gentili on the Legal Character of the Global Commonwealth
}

\author{
Andreas Wagner \\ (20 January 2011)
}

This is a pre-copy-editing, author-produced PDF of an article accepted for publication in Oxford Journal of Legal Studies following peer review. The definitive publisher-authenticated version [Wagner, Andreas: "Francisco de Vitoria and Alberico Gentili on the Legal Character of the Global Commonwealth", in OJLS 31/3 (2011): 565-582; doi: 10.1093/ojls/gqr008] is available online at: http://ojls.oxfordjournals.org/content/31/3/565 


\title{
Francisco de Vitoria and Alberico Gentili on the Legal
}

\section{Character of the Global Commonwealth}

\begin{abstract}
ANDREAS WAGNER*
Abstract-In discussing the works of 16th-century theorists Francisco de Vitoria and Alberico Gentili, this article examines how two different conceptions of a global legal community affect the legal character of the international order and the obligatory force of international law. For Vitoria the legal bindingness of ius gentium necessarily presupposes an integrated character of the global commonwealth that leads him to as it were ascribe legal personality to the global community as a whole. But then its legal status and its consequences have to be clarified. For Gentili on the other hand, sovereign states in their plurality are the pinnacle of the legal order(s). His model of a globally valid ius gentium then oscillates between being analogous to private law, depending on individual acceptance by states and being natural law, appearing in a certain sense as a form rather of morality than of law.
\end{abstract}

Keywords-International law, legal history, legal philosophy, Alberico Gentili, Francisco de Vitoria, global legal community.

Undeniably, over the last decades, an international society has taken shape which corresponds largely to Vitoria's conception of a universal society: ... The attribution of autonomous lawmaking power to international society, transcending the need for individual acceptance by its States, but based on the consent of the larger part of society, is reflected in the general principles of international law recognized as sources of international law. ${ }^{1}$

Many current controversies in the theory of international law hinge on some notion of a universal legal community that can on its own sustain and possibly even generate legal obligations for its members. In fact, one of the major issues today is the quarrel between theories of legal pluralism and those of legal universalism, with the latter drawing heavily on ideas of a global legal community, for example in grounding the public or even constitutional aspects of international law

\footnotetext{
${ }^{*}$ Cluster of Excellence 'The Formation of Normative Orders', University of Frankfurt/Main, Germany. Email: Andreas.Wagner@em.uni-frankfurt.de. I owe great debt to my colleagues in the Cluster's research project on the School of Salamanca, Matthias Lutz-Bachmann, Kirstin Bunge, Matthias Schweighöfer and Anselm Spindler, who together constituted the better part of an almost ideal collaborative research environment. In 2009 we held a conference on 'The Normativity of Law in the School of Salamanca', from the participants of which I have received valuable feedback on some of the ideas presented here. I am grateful for further helpful comments and suggestions from Ben Kamis, Thomas Kleinlein, Andreas Niederberger and Benjamin Straumann. I also wish to thank the OJLS's anonymous reader, who has kindly offered points of critique that led me to re-think and clarify some of the arguments, which certainly has made this paper better. Any remaining oddities fall of course under my own responsibility.

${ }^{1}$ Judge Rosalyn Higgins, President of the International Court of Justice, 'Address on the occasion of the presentation of the Francisco de Vitoria medal to the International Court of Justice by the city of Vitoria' (5 April 2006) $<$ http://www.icj-cij.org/presscom/index.php?p1=6\&p2=1\&pr=1002> accessed 18 January 2011.
} 
or in explaining the substantive character of certain fundamental legal values. ${ }^{2}$ In this essay, I argue that two different conceptions of the legal character of a global community can be discerned in two authors of early modern international law: Both Francisco de Vitoria (1483-1546) and Alberico Gentili (1552-1608) have developed ideas of how a global community of mankind makes international law apply globally, but they differ in the understanding of its normative character. ${ }^{3}$ One of the central differences concerns the understanding of international law as a set of norms that are originating in human lawmaking and at the same time binding also those who did not assent to them. In systematic terms, the contrast between the two authors suggests that the legal conceptualization of the global community lies at the point of bifurcation between a multilateral and a public understanding of international law or, to name a more concrete example, between a 'bi-/unilateral' and a 'punitive' understanding of the legal consequences of internationally wrongful acts. ${ }^{4}$ Put in those terms, the suggested historical analysis may serve as an inspiration for presentday discussions of international law, although this is not discussed here in any detail. ${ }^{5}$

\section{Francisco de Vitoria}

Central to Francisco de Vitoria's understanding of law in general is its relation to the community that it regulates. His relectio on the civil power of 1528 puts forward an argument according to which political power (potestas civilis) and commonwealth (res publica) are constituted as relata,

\footnotetext{
${ }^{2} \mathrm{Cf}$ eg A von Bogdandy and S Dellavalle, 'Universalism and Particularism as Paradigms of International Law' (IILJ Working Paper 2008/3) < http://www.iilj.org/publications/2008-3Bogdandy-Dellavalle.asp> accessed 18 January 2011. For other contributions to the universalist argument and its reliance on ideas of a global legal community, cf $\mathrm{M}$ Payandeh, Internationales Gemeinschaftsrecht (Springer, Heidelberg 2010); R Domingo, The New Global Law (CUP, Cambridge 2010); A Paulus, Die internationale Gemeinschaft im Völkerrecht (Beck, München 2001).

${ }^{3}$ For the purposes of this text, I assume that it is possible to use 'international law' in referring to the notion of 'ius gentium' and similar delicate translations. Whether or not these can be justified is out of scope for the present article (although I submit they can), hence they have to be taken with a grain of salt. Also, it should be mentioned that I am using the term 'positive law' not in the sense of 'statutory law', but of 'not natural/necessary law', so that it also encompasses customary law, and that by 'public law' I am referring to the law of a civic condition that is created and susceptible to being enforced without or even against the will of the affected subjects.

${ }^{4} \mathrm{Cf}$ A Blane and B Kingsbury, 'Punishment and the ius post bellum' in B Kingsbury and B Straumann (eds), The Roman Foundations of the Law of Nations: Alberico Gentili and the Justice of Empire (OUP, Oxford 2010) 241-265, and the non-historical debates in Paulus (n 2) 386-413 and Payandeh (n 2) 369-431. All of these refer to ILC, 'Articles on the Responsibility of States for Internationally Wrongful Acts' in ILC, 'Report of the International Law Commission on the work of its 53rd session' (2001) UN Doc A/56/10.

${ }^{5} \mathrm{~A}$ similar reasoning may have motivated other contributions addressing historical ideas of humanity as a legal concept, like eg T Meron, 'Common Rights of Mankind in Gentili, Grotius and Suárez' (1991) 85 AJIL 110-116; C Focarelli, 'On the concept of "International Community as a Whole” in International Law' (2007) 14 Journal of International Cooperation Studies 51-70.
} 
that is, they are inseparable and can be conceptualized only in relation to one another. ${ }^{6}$ Being the focal point of the common or public good, political power is the catalyst for the very existence of a commonwealth and the condition of its coherence over time. Vice versa, since there is no a priori localization of that political power, every actual instance of it must be proven in some way (eg by election) to correspond to the commonwealth itself first. ${ }^{7}$ Political power then has a factual and a normative aspect to it, it is a de facto power the public character of which has been acknowledged: 'Public power is the faculty, authority or right to govern the civil commonwealth., ${ }^{8}$ Thus, potestas is not a sociological, but a legal concept; it is factual power reflexively embedded in a legal order. Correspondingly, the exercise of political power, the governance of the commonwealth consists precisely in operating the mechanics of the legal order: to "frame laws, propose policies, judge disputes, punish transgressors'. ${ }^{9}$ Conversely, the acknowledgement of the political power by the commonwealth is a legal act as well; it is a constitutio translatione auctoritatis. ${ }^{10}$ In this sense, public power and political commonwealth are articulated and jointly constituted only in legal practice. This conjunctural nature of law, political power and commonwealth implies a distinct normative quality of their union, which cannot be reduced to an aggregation of the qualities of isolated elements, but which grounds their normative claims in the first place.

Based on the fundamental but abstract necessity of the connection between commonwealth and political power, the question of the specific institutional form of government is of a different nature

${ }^{6}$ Francisco de Vitoria, 'On Civil Power' in idem, Political Writings (ed A Pagden and J Lawrance, CUP, Cambridge 1991) 1-44. Throughout this essay, I cite this as CP. For all texts I supply the page number of the used editions in square brackets. On the genres of relectiones and lecturae and on the history of their editions cf A Sarmiento, 'Lecturas ineditas de F. De Vitoria. Bases para la edicion crítica' (1980) 12 Scripta Theologica 575-592.

${ }^{7}$ In Vitoria's terms: the commonwealth 'cannot exist' without governing power (CP $\S 5$ [9]) and at the same time it is the 'material cause' of this power (CP $\S 7$ [11]). For a discussion of this mutual dependency, cf A Niederberger, 'Recht als Grund der res publica und res publica als Grund des Rechts' in K Bunge, A Spindler and A Wagner (eds) Die Normativität des Rechts bei Francisco de Vitoria (Frommann-holzboog, Stuttgart 2011, forthcoming).

${ }^{8} \mathrm{CP} \S 10$ [18], transl. modified. There is some difficulty in translating this potestas: Vitoria never actually speaks of 'potestas politica' and although using 'civil power' might have emphasized the institutional framework with which Vitoria's 'potestas civilis' is necessarily connected, here I prefer 'political' power for reasons of common usage. Compare M Barbier, 'La notion de res publica chez Vitoria' in YC Zarka (ed), Aspects de la pensée médiévale dans la philosophie politique moderne (PUF, Paris 1999) 83-101, here 87 fn 1.

${ }^{9} \mathrm{CP} \S 8$ [14]. At various places, Vitoria calls this 'administratio' or 'gubernatio'. At other places, he uses 'tutela', but always in self-reflexive verb form, as in 'potestas tuendi se', or, yet another term, 'potestas dirigendi se'. In sum, he is not overly concerned in fixing this class of actions terminologically. Yet with legislation, administration, jurisdiction and punishment he obviously has very specific actions in mind.

${ }^{10} \mathrm{CP} \S 8$ [16f], 12 [21]. 
and up to the commonwealth itself to decide autonomously. ${ }^{11}$ The normative dignity of the particular government then - be that prince, senate or some other group of persons - has two roots: One is the set of competences resulting from its legislative and executive position within the societal order of rules and laws, the other is a normative correspondence between it and the commonwealth's self-determination. Since the latter motive is not merely a question of either/or, but a substantial response to the features of the government, it is not only a justification of it, but also a specification and in a sense even a limitation. ${ }^{12}$ The distinction between the two motives is rendered by Vitoria in distinguishing 'potestas' and 'auctoritas' in his discussion of royal power:

Royal power (regia potestas) clearly comes immediately from God himself, even though kings are created by the commonwealth. That is to say, the commonwealth does not transfer to the sovereign his power (potestas), but his own authority (propria auctoritas); there is no question of two separate powers, one belonging to the sovereign and the other to the community. ${ }^{13}$

This foundation of political power has very concrete consequences. First, it provides the foundation of the principle of majority rule. For given such a collective entity capable of action, why should a minority have the power to decide that nothing is to be done by the collective rather than the majority have the power to decide that something be done by it?

When there are two dissenting parties in the administration of the commonwealth, if each holds contradictory opinions, one of the two must necessarily prevail; but in this case the opinion of the minority should clearly not prevail, and therefore the opinion of the majority must be followed. ... Should any greater consensus be required for a positive action than for a negative one? ${ }^{14}$

Second, and more important for the present purpose, the distinction between 'auctoritas' and 'potestas' explicates that the obligatory force of laws thus has two normative aspects - first, they are not so much particular commands as norms that are part of a factual system of normative social

\footnotetext{
${ }^{11} \mathrm{CP} \S 14[32]$.
}

${ }^{12} \mathrm{Cf}$ also Vitoria, 'On Law: Lectures on ST I-II. 90-105' in idem, Political Writings (n 6) 153-204, here q 105, art 2 [200-204]. In this sense he can also say that a prince always holds his office by election as in Vitoria, 'On the Law of War' in idem, Political Writings (n 6) 293-327, here q 1, art 2, § 6 [301]. Similarly, this constellation can explain why at several places Vitoria holds that 'whatever laws the commonwealth can pass, ... the king can pass the same' and yet at the same time insist that 'the king cannot do everything that the commonwealth can' (Vitoria, 'On Law' q 105, art 2 [201f]).

${ }^{13} \mathrm{CP} \S 8$ [16f], transl. modified. Note however, that in $\S 14$ [31] Vitoria explains royal power as being formed when the commonwealth gives power (dat potestatem) over the citizens to a single man. My interpretation of the relation auctoritas/potestas draws heavily on A Miaja de la Muela, "El derecho "totius orbis" en el pensamiento de Francisco de Vitoria' (1965) 18 Revista Española de Derecho Internacional 341-364, esp. 352-362. Cf also A Pagden 'Introduction' in Vitoria, Political Writings (n 6) xiii-xxviii, here esp xix - xxi.

\footnotetext{
${ }^{14} \mathrm{CP} \S 14[30]$.
} 
coordination which imparts its benefits on obedience to them (potestas), and second, they are related to the practical reason and political experience of the commonwealth as a collective actor (auctoritas). The latter moment makes the normative validity of laws to a certain extent independent of the institution that de facto creates them (that is, independent of the potestas of a legislative institution). This can explain how, notwithstanding his superiority to the citizens supra omnes simul, the king is bound by his own laws: The vis legis of the laws originates not only in the legislative competence of the prince, it is not imparted on them only in their actual making. (Neither is it due to their being authorized by God.) But they may, and normally do enjoy mediate or maybe even sometimes immediate authorization by the commonwealth itself. ${ }^{15}$

[L]aws passed by a king have the same force (vis) as if they were passed by the whole commonwealth, as explained above. But laws passed by the commonwealth bind everyone hence they bind the king, even if he himself passed them. ${ }^{16}$

In a famous passage in the same article, Vitoria extends this argument to the norms of ius gentium and emphasizes how their vis legis, in contrast to the lesser obligatory force of mere pacta and condictiones, is connected to the public power of a commonwealth:

[T] he law of nations does not have the force merely of pacts or agreements between men, but has the force of law (vis legis). The whole world (totus orbis), which is in a sense a commonwealth, has the power to enact laws (potestas ferendi leges) which are just and convenient to all men; norms like these make up the law of nations. ... No kingdom may choose to ignore the law of nations, because it is given by the authority of the whole world (est latum totius orbis auctoritate). ${ }^{17}$

As Adolfo Miaja de la Muela has shown, Vitoria seems to suggest that, while the global commonwealth de iure has potestas ferendi leges, there is no concrete institution that could enact this de facto and thus there is no statutory law - lex - at this level. However, there are unwritten norms - ius -, and whatever their origin is, they gain normative validity via the global commonwealth's auctoritas. ${ }^{18}$ In this manner, their obligatory force on the one hand corresponds to

\footnotetext{
${ }^{15}$ Ibid.

${ }^{16}$ Ibid $\S 21$ [40], transl. modified and emphasis added. The use of the 'as if' (ac si ferrentur) indicates that, on Vitoria's account, the obligatory force of legal norms does not depend on their de facto creation, but on an authorization by the commonwealth that could even be a legal fiction - the crucial criterion being whether they are equitable and convenient for the commonwealth. See also Vitoria's account of in what sense and under which conditions even the laws of a tyrant are binding, ibid $\S 23$ [42] and in Vitoria, Comentarios a la Secunda secundae de Santo Tomas, vol III: De iustitia (ed V Beltrán de Heredía, Apartado, Salamanca 1934) q 60 art 6 [54]. Note how the acknowledgement of equity and convenience is not a matter to be judged by the natural reason of individual persons qua singuli but (in some way that is in need of explanation) a matter of collective reasoning. Also, note how Vitoria in this whole discussion does not pursue Thomas Aquinas' argument of a difference between vis coactiva and vis directiva.
}

${ }^{17}$ Ibid art 21 [40], transl. modified.

${ }^{18} \mathrm{Cf}$ A Miaja de la Muela (n 13). 
the universal and public character of the global commonwealth, and on the other hand it is perfectly consistent with them not being necessary or natural law. ${ }^{19}$

And for Vitoria, there is no question whether such a commonwealth exists on a global, "international" level. In addition to the just mentioned statement about the "whole world which is in a sense a commonwealth', the very first of the 'legitimate titles', eventually justifying an intervention of the Spanish in the New World in his Relectio de Indis of $1539,{ }^{20}$ is the title of 'natural partnership and communication. ${ }^{21}$ From this follow rights of, among others, travel and commerce, and from it also follows a right to tell the truth (preach the gospel). ${ }^{22}$ Although on first view the "naturality" of the "natural partnership' seems unequivocal with regards to the status of the global community itself, on second thought it has a peculiar status: The mentioned article uses the formulation in giving a name to a legal title, but looking at the title's justification, the community in question is relied upon neither as a fact nor as a normative demand. Rather, it is presented as normative idea necessarily presupposed by all kinds of rights, demands and contracts, such as the contract in which the original division of property and jurisdictions has been decided.

This point [that is, that no divine law has constituted a global empire] can be easily understood by anyone who examines the method of succession by which the empires and dominions of the world have been handed down to our day. ... [I]t is clear that after Noah the world was divided into various countries and kingdoms. This was either ordered by Noah himself, ... or, as seems more likely, [was done] by mutual consent of the nations (consensu mutuo gentium), as various families colonized different countries. ${ }^{23}$

This picture of a presumed consensus leading to the establishment of different realms is not so much a historical assertion about the genealogy of nations and the historical priority of some global community, it is rather a sort of praesumtio iuris. It serves first of all to explain and justify the present landscape of legal entities, but also as a resource to assess further legal questions. ${ }^{24}$ One of the main points it conveys is this: Since by natural law humankind was in common possession of the earth, if the foundation of the many particular commonwealths is to be legally effective, it has to

\footnotetext{
${ }^{19}$ Both aspects are also emphasized by Miaja de la Muela, ibid 348-352.

${ }^{20}$ Vitoria, 'On the American Indians' in idem, Political Writings (n 6) 231-292, henceforth cited as OAI.

${ }^{21}$ Ibid primus titulus legit., q 3, art 1, § 1 [278]: 'First just title, of natural partnership and communication.'

${ }^{22}$ For the relation between secular and theological aspects of Vitoria's discussion, and for further explication of the presently suggested, admittedly rather secular reading of Vitoria, cf A Spindler, 'Vernunft, Gesetz und Recht bei Francisco de Vitoria' in Bunge/Spindler/Wagner (eds), Normativität des Rechts (n 7) and A Wagner, 'Die Theologie, die Politik und das internationale Recht. Vitorias Sprecher- und Akteursrollen' in N Brieskorn and G Stiening (eds), Francisco de Vitorias De Indis in interdisziplinärer Perspektive (Frommann-holzboog, Stuttgart 2011, forthcoming).

${ }^{23}$ Ibid primus titulus illegit., q 2, art 1, § 25 [255].

${ }^{24} \mathrm{Eg}$ in an assessment of the possibility of some prohibition on free travel, OAI, primus titulus legit., q 3 , art $1, \S 2$
} [278]. 
be understood as being a result of positive lawmaking by the global commonwealth.

The claims of a particular political entity, gens or natio, that has been constituted as bearer of claims in the original divisio rerum are then conditioned by encompassing communities that have either been constituted supervening upon the one in question (as Christianity has been) or that have to be presupposed (as the global commonwealth has to be). Hence a war that would be objectively justified if one took into account a particular commonwealth in its relation to another particular commonwealth might become unjust and illegal by its consequences for the wider commonwealth:

Since any commonwealth is part of the world as a whole (pars totius orbis), ... I should regard any war which is useful to one commonwealth or kingdom but of proven harm to the world ... as, by that very token, unjust. ${ }^{25}$

But not only does this concept put limits on the external actions of particular commonwealths, it also provides a justification for active intervention into them: In the second relectio on the question of the Indians, usually called Relectio de iure belli, Vitoria argues that if it is necessary for the finis et bonum totius orbis, the right of a particular commonwealth not to be interfered with is superseded or trumped by the public interest in prosecution and law enforcement.

A seventh proof [for the permissibility of war, AW] is based on the purpose and good of the whole world. Surely it would be impossible for the world to be happy ..., if tyrants ... were able to injure and oppress the good and the innocent without punishment .... ${ }^{26}$

Whereas the divisio rerum, as an act of public policy has established "private" realms for each of the particular communities, they all have to remain within the constitutive parameters of the global commonwealth. The freedoms private actors have in their affairs are protected, determined and limited by a public framework, the authority of which is different from the titles any private actor might have. Matters of self-government are one thing, and they do have an external aspect in terms of self-defence and enforcement of restitution, but the very existence of the global legal order is quite another thing, and it is this which implies public authority and power to punish - 'otherwise the world could not exist'. ${ }^{27}$

It is important not to confuse the insistence on public authority with a denial of private autonomy and of subjective rights: Vitoria's conception is not one of "objective right", "organicism" or "holism" where in every case the more encompassing and more dignified community would be determining the role and value of every subordinate subject and its rights. Individual right-bearers in the sense of natural persons just do not need to be authorized and institutionalized in the same

\footnotetext{
${ }^{25} \mathrm{CP} \S 13$ [21].

${ }^{26}$ Vitoria, 'On the Law of War' (n 12) q 1, art 1 [298]. Note that the concept is indifferent as to whether the 'good and the innocent' are the tyrant's own subjects or not.

${ }^{27}$ Ibid q 1 , art 4, § 5 [305], transl. modified.
} 
way as political institutions. ${ }^{28}$ The protection of their (fundamental) rights is the ground for the global commonwealth, and these rights are not at the disposal of any political potestas or auctoritas, however universal these may be. ${ }^{29}$

Let that be sufficient to show how Vitoria imagines the foundation of central aspects of the obligatory force of ius gentium. He has managed so far to discuss this with surprisingly little attention to how this law is created de facto - and he has hinted at why this may in fact not matter much. But even granted that the factual sources of law maybe need not justify the law's normative claim, it is advisable to reflect briefly on their relation to the source of this normative claim, as outlined above, especially given that on the global level there is de facto no constituted global potestas and that hence it is unclear where the norms that are susceptible to being authorized by the global commonwealth are coming from in the first place. ${ }^{30}$

Now, while Vitoria emphasizes that the norms of ius gentium possess vis legis, as far as I am aware he never uses the term leges for them. With the freedoms of travel, commerce and truthtelling, delimitations of particular jurisdictions, prohibition on the externalization of costs of domestic self-government etc, he has very concrete (and far-reaching) rules in mind, ${ }^{31}$ but as ius gentium they are surely not statutory law. In his commentary on Thomas Aquinas's treatise on law, one can see how he prefers to treat statutory norms of civil (or canon) law as paradigmatic cases of leges, and there he does not even mention the ius gentium. However, in this text he explains how

\footnotetext{
${ }^{28}$ In 'On the American Indians', Vitoria submits that every human being is endowed with legal personality. Cf OAI q $1[239-251]$.
}

${ }^{29}$ This can be seen from Vitoria's discussion of tyranny in OAI quintus titulus legit., q 3, art 5 [287f]; Vitoria, 'On Dietary Laws, or Self-Restraint' in idem, Political Writings (n 6) 207-230, here q 1, art 5 [225f]; Vitoria, 'On Law' (n 12) q 105, art 2, prop 13 [204]; and Vitoria, De iustitia (n 16) q 64, art 6 [298-302]. Cf also A Wagner, 'Zum Verhältnis von Völkerrecht und Rechtsbegriff bei Francisco de Vitoria' in Bunge/Spindler/Wagner (eds), Normativität des Rechts (n 7).

${ }^{30}$ It may be worthwhile to note that in spite of all similarities, Domingo de Soto (1494-1560), a close collaborator of Vitoria focuses much more on the actual exercise of governmental, above all legislative functions - and ends up denying the plausibility of the idea of a global commonwealth. Cf eg Domingo de Soto, De iustitia et iure libri decem, vol II (ed V Diego Carro, Instituto de Estudios Políticos, Madrid 1968) lib IV, q 4 a 2 [304]; on the contrast between Soto and Vitoria, cf also R Tuck, The Rights of War and Peace (OUP, Oxford 1999) 73-75 and A Wagner, 'Domingo de Soto über die communitas totius orbis' in K Bunge, S Schweighöfer, A Spindler and A Wagner (eds), Recht zwischen Philosophie, Theologie und Jurisprudenz: Beiträge zur Begriffsgeschichte zwischen Francisco de Vitoria und Francisco Suárez (Frommann-Holzboog, Stuttgart 2011, in preparation).

${ }^{31}$ The mentioned freedoms are developed in the first two legitimate titles in OAI q 3, art 1f [278-286]. With regards to the delimitations of jurisdictions, Vitoria holds that 'for the most part these matters are done according to the law of nations or human law' (Vitoria, 'On the Law of War' (n 12) q 1, art 2 § [302]). As can be learned from 'On the Law of War' (ibid q 1, art 4, $\S 13 \mathrm{f}$ [303f], if burdens illegitimately imposed on others qualify as (very) serious iniuria, they may justify recourse to such extreme measures as war. 
one other type of norms that are not leges can acquire vis legis: customs. ${ }^{32}$ Prima facie customs do not possess that force, but can acquire it when they can be interpreted as 'signs' for a corresponding intention of the legislator. ${ }^{33}$ Yet the pure facticity of a social or princely custom is not a sufficient ground for such an interpretation; it has to be supplemented by either the verdict of sapientes or by customary authoritative punishment of transgressors. In the case of ius gentium then, where a legislating institution is lacking, the legislator whose intention is to be inferred is the global commonwealth as a whole (whose existence must be presupposed for reasons described above). With regards to the multi-level legal environment of the res publica totius orbis, Vitoria can connect this argument with the majority principle to take convergent municipal laws, which imply punishment of transgressors and explicit adoption by multiple particular commonwealths, as signs for the intention of the global legal community. The normative authority of particular commonwealths - or even of their governments - on the municipal level is transformed into an epistemic authority on the international level and cannot decide on, but effectively contribute to, the recognition of rules of ius gentium.

[I]f the law of nations is derived in a sufficient way from natural law, it is manifestly able to create binding rights. But given that it is not always derived from natural law, it seems to result from the consent of the greater part of the world, especially when it is for the common good of all men. If, after the dawn of creation or after the refashioning of the world following the Flood, the majority of men decided that the safety of ambassadors should everywhere be inviolable ..., then that certainly has binding force, even if some disagree. ${ }^{34}$

As a last point, I want to briefly emphasize once again the 'positive law'-character of Vitoria's ius gentium: His presentation of its norms - be that the immunity of legates, the original divisio rerum or the qualification of some 'imperfect' commonwealths as nonetheless competent to wage war ${ }^{35}-$ usually conveys that those norms are products of human practical reason that could, logically speaking, have turned out differently. The merely epistemic role that particular authorities sometimes assume does not imply that these norms are in some way naturally given or without alternative. In the previously quoted passage, the consent of the majority is necessary and sufficient precisely in cases where no derivation from necessary principles (that is, natural law) is possible.

\footnotetext{
${ }^{32}$ Vitoria, 'On Law' (n 12) q 97 art 3 [185f].

${ }^{33}$ Vitoria uses the concept of auctoritas in his first proposition again: "no custom can be binding ... except by the express authority of the superior power (ex intentione et auctoritate superioris)' (ibid [185]), but in the remainder of the article he speaks rather of intentio and voluntas. The role of the sapientes hints at the rational accessibility of authority again, however.

${ }^{34}$ OAI primus titulus legit., q 3, art 1, $\$ 4$ [281], transl. modified. As we have seen, the consent of the majority can be sufficient to create public obligations (also for those who did not partake in the consensus) only given the wider framework of a republican commonwealth.

${ }^{35}$ Vitoria, 'On the Law of War' (n 12) q 1, art 2, § 9 [302].
} 
This is also confirmed when Vitoria describes the task of legislation in toto as one more of a probabilistic than of a determinate nature:

Many of those things - also of those that a prince suitably commands - cannot be accounted for with self-evidential reasons, but only with probable ones. ${ }^{36}$

\section{Alberico Gentili}

The Italian protestant and Regius Professor of Civil Law at Oxford Alberico Gentili is also frequently counted among the founders of modern international law, especially insofar as, taking up ideas of Bodin's theory of sovereignty, he suggested an even more independent role of the states in international law. ${ }^{37}$ Far from presenting an outright positivist theory of international law, in his arguably most important text De iure belli libri tres (1598) he starts out from a classical definition of ius gentium which focuses on naturalis ratio. Joining to it an idea of successive acceptance by all men, he develops a model of international law which is at first glance not unlike Vitoria's:

[The founders and authors of our laws] say that the law of nations is that which is in use among all the nations (gentes) of men, which native reason has established among all human beings and which is equally observed by all mankind. Such a law is natural law. ... But that which has successively seemed acceptable to all men should be regarded as representing the intention and purpose of the entire world (totius orbis decretum fuisse existimetur). ${ }^{38}$

The combination of natural reason and historical acceptance hints at a complicated tension. In fact,

\footnotetext{
${ }^{36}$ Vitoria, 'On Dietary Laws, or Self-Restraint' (n 29) q 1, art 5 [220], transl. modified.

${ }^{37}$ For David Kennedy, his reversal of the asymmetry of power between the sovereigns and the global order in comparison to the 'Spanish scholastics' marked 'the beginning of the end of primitive scholarship'; cf D Kennedy, 'Primitive Legal Scholarship' (1986) 27 HILJ 1-98, here 58f. Cf also JL Holzgrefe, 'The Origins of Modern International Relations Theory’ (1989) 15 Review of International Studies 11-26. Regarding the contrast to Vitoria, cf D Panizza, 'Political Theory and Jurisprudence in Gentili's De iure belli. The great debate between "theological" and “humanist" perspectives from Vitoria to Grotius' (IILJ Working Paper 2005/15) <http://www.iilj.org/publications/200515Panizza.asp $>$ accessed 18 January 2011; and with regards to Gentili's enduring importance cf B Kingsbury, 'Confronting Difference: The Puzzling Durability of Gentili's Combination of Pragmatic Pluralism and Normative Judgment' (1998) 92 AJIL 713-723. The classical attribution of parenthood of modern international law to Gentili is Thomas E. Holland's 'Inaugural Lecture' from 1874, in TE Holland, Studies in International Law (Clarendon, Oxford 1898) 1-23. See also P Haggenmacher, 'Grotius and Gentili: A Reassessment of Thomas E. Holland's Inaugural Lecture' in H Bull, B Kingsbury and A Roberts (eds), Hugo Grotius and International Relations (Clarendon, Oxford 1992) 133-180.

${ }^{38}$ Alberico Gentili, De iure belli libri tres, vol 2 (ed. J Brown Scott, Clarendon, Oxford 1933) lib I, ch I [8]. For further arguments contrasting Gentili's ideas of 'totus orbis' with those of the Spaniards, cf the texts referenced above (n 5) and most recently A Pagden, "Gentili, Vitoria and the Fabrication of a "Natural Law of Nations" in Kingsbury/Straumann (eds), Roman Foundations (n 4) 340-361.
} 
we can identify motives both of natural law and of an empirical, positive law in Gentili's concept of international law. ${ }^{39}$ In what follows I want to pursue these further and argue that neither motive covers a quasi-republican public international legal order of a kind comparable to the one described above, and that instead both motives end up with a bi- or multilateral concept of obligation that cannot de jure overcome the objection of a sovereign state which does not want to be obliged.

The argument of successive acceptance at the end of the quoted passage is located in the context of the question of in what sense 'all human beings' (from the preceding definition) is to be understood. Before saying anything about natural law, Gentili explains that when one does not understand 'all' in an absolute sense, one has a large enough set of peoples providing empirical evidence on the basis of which reliably to compile the laws of the nations. Thus, taking up again the argument of successive acceptance, he argues that one should find out what rules the majority of humans de facto customarily observe.

$[\mathrm{A}] \mathrm{s}$ the rule of a state and the making of its laws are in the hands of a majority of its citizens, just so is the rule of the world in the hands of the aggregation of the greater part of the world. Moreover, this is especially true of the unwritten law; for a custom is binding upon all the members of a state and is called the custom of the entire state, even if every citizen has not agreed to it, but haply some have even opposed it. ${ }^{40}$

Having thus shifted the focus to unwritten laws and custom, Gentili presents us with an argument which he considers more adequate, but which amounts to saying that these customs cannot have been made by men:

But there is another more elegant definition of the law of nations ..., that there are everywhere certain unwritten laws, not enacted by men ..., but given to them by God. ... Such laws are not written, but inborn; we have not learned, received, and read them, but we have wrested, drawn, and forced them out of nature herself. We have not received them through instruction, but have acquired them at birth; we have gained them, not by training, but by instinct. ${ }^{41}$

For Gentili, natural law is the foundation of international law, or both are even identical. He adduces natural reasons' self-evidential character, the examples of philosophers and wise men who usually speak and act according to nature, ${ }^{42}$ and arguments and reasons of his own as material for formulating the laws of nations. Thus, rather than explaining how the majority of mankind could be imagined as and justified in legislating for the whole, he offers as the main resource for international law's binding force ('ita ius defenditur gentium') the moral nature of man which

\footnotetext{
${ }^{39} \mathrm{Cf}$ J Waldron, 'Ius Gentium: A Defence of Gentili's Equation of the Law of Nations and the Law of Nature' in Kingsbury/Straumann (eds), Roman Foundations (n 4) 283-296.

${ }^{40}$ Gentili, De iure belli libri tres (n 38) lib I, ch I [9].

${ }^{41}$ Ibid [9f]

${ }^{42}$ Ibid [10f].
} 
provides for an inexplicable sentiment that transgression cannot be justified. ${ }^{43}$ In this manner, the majority no longer legislates but rather exemplifies and reveals the nature present in every human being. ${ }^{44}$

Neither when speaking of natural law and natural reason, nor when relying on factual customs of the diverse peoples does Gentili understand the norms of ius gentium as deriving from the intentions of any global lawgiving community. Quite to the contrary, even when discussing customs, he is presenting them as developments of (reasonable) human nature. Hence there is not even a need to identify some opinio iuris, to infer a legislative intention from factual custom, because the latter is already binding with "natural authority". In other words, the norms of international law to which the nations are subject are not thought of as positive law. As we are going to see, insofar as positive international law would imply a (virtual) lawgiver and/or judge to which they would have to submit, it would even contradict Gentili's conception of a sovereign nation.

But after all Gentili does have a concept of the global commonwealth, does he not? If so, then what is it, if it is not a lawgiving community? As was the case with Vitoria, it appears prominently in the discussion of war for the purpose of helping others (Gentili: bellum honestum). But note how Gentili is presenting descriptions of the community that combine ethical and legal vocabulary, speaking of amor and benevolentia on the one hand and of civitas and res publica on the other:

[Defence for honour's sake] rests upon the fundamental principle, that nature has established among men kinship, love, kindliness, and a bond of fellowship (as Marcus Tullius says); and that the law of nations is based upon this association of the human race. It is precisely for that reason that the law of nations is called by Cicero 'civil'. In fact, the Stoics maintained that the whole world formed one state (civitatem totius mundi unam esse) ... Now you have heard that the whole world is one body, that all men are members of that body, that the world is their home and that it forms a state. Listen to these words once more, for they are beautiful. ... Lactantius calls the world a commonwealth (res publica). It is a great state, having the form of

${ }^{436}$ These things are so well known, that if you should try to prove them, you would render them obscure. ... It has been made sufficiently clear that natural law does exist, and that if you should transgress it in any particular, you would desire to conceal the act through very shame. Or if you should go so far in shamelessness as to confess and try to justify the action, you would have the same feeling that one has towards those statements which are called axioms, namely, you would instinctively feel that the act could not be justified.' (Ibid [10]).

${ }^{44}$ If we turn to his justification of the law of embassies, which in our discussion of Vitoria was reflecting the positive character of ius gentium, we see how Gentili again gives it a more natural character. For after the nations and realms had been separated and law had been established, 'those having contiguous territory began to form friendly compacts, and to refrain from doing injury or violence to one another. ... But since it was inevitable that obligations and negotiations should arise between organizations having such reciprocity of rights as exists between nations, commonwealths and kings, and since those organizations are either unwilling or, as often happens, unable to meet (certainly states cannot meet), it was absolutely necessary ... that others should be appointed, who by representing the organizations would be able to transact the necessary business.' (Alberico Gentili, De legationibus libri tres, vol II (ed J Brown Scott, OUP, New York 1924) lib I, ch XX [51], emphasis added). 
one commonwealth and one code of laws, says Philo. The one commonwealth of all, and the common city of all, say Tertullian and Minucius. ${ }^{45}$

However, Gentili seems to think that this has not quite resolved the question, given that a bit later, he is asking again: 'Quid vero ista societas et coniunctio?' And again he answers with citations, only this time the "legal-political" vocabulary no longer appears at all, and the citations focus exclusively on benevolentia and caritas as a kind of social instinct implanted in human nature. ${ }^{46}$ If the global commonwealth then is rather an ethical concept, an ideal telos of our human nature, it certainly cannot in fact establish concrete norms of ius gentium that are unconditionally binding in the context of interactions between sovereign heads of states. The claim of their behaviour being legally regulated is founded on an analogy of rationes instead of on the legal authority of a global commonwealth:

Now what Plato and those expounders of the law say of private citizens we feel justified in applying to sovereigns and nations, since the rule [ratio] which governs a private citizen in his own state ought to govern a public citizen, that is to say a sovereign or a sovereign people, in this public and universal state formed by the world. As a private citizen conducts himself with reference to another private citizen, so ought it to be between one sovereign and another. ${ }^{47}$

The princes (ought to) stand in relation to one another just as private persons do in the municipal realm. They have a certain repertoire of legal instruments at their disposal which they can put to the service of their own particular interests. But the crucial difference is that municipal private law is backed by public authority - of the particular community as a whole and of the sovereign who governs it. This authority transcends the particular authority or legal power of the individual private actors. And a similar authority is lacking with regards to the relations between sovereigns.

Thus there is no possibility of an agent acting publicly in the sense of acting on behalf of the global commonwealth: When discussing the question of whether cross-border acts of individuals should count as private or public acts, Gentili holds that there are empirical criteria for identifying the publicness of an act or agent. For even the behaviour of the relevant community as a whole need not necessarily be regarded as its public action. What counts is a formalized deliberation of an

\footnotetext{
${ }^{45}$ Gentili, De iure belli libri tres (n 38) lib I, ch XV [67].

${ }^{46}$ Commenting the same passages, D Panizza, "The "Freedom of the Sea" and the "Modern Cosmopolis" in Alberico Gentili's De iure belli' (2009) 30 Grotiana 88-106, emphasizes the 'pivotal role' that the concept of a society of mankind played for Gentili, justifying offensive wars in support of 'humanity' and 'liberty' and also against violations of 'the common law of humanity', of 'wrongs done to mankind'. But he goes on: 'For Gentili, both kinds of war were instances of a distinctive common moral category, namely as wars undertaken for the sake of "honesty" as opposed to wars undertaken for the sake of “utility”, or of self-preservation.' (Ibid 94, emphasis added.) Of course moral arguments like these can be used in justifying military enterprises, but can they function as legal titles?

${ }^{47}$ Gentili, De iure belli libri tres (n 38) lib I, ch XV [68]. It should be noted that this passage does not imply the inclusion of private individuals as subjects of ius gentium. Cf also below, note 57.
} 
assembly which has been convened in a specific, customarily defined manner. It is this purely factual institutional framework that provides for the possibility of legally ascribing to individuals a public role.

'When [is] an act ... public and when [is it] private'. Undoubtedly a wrong is greater which is committed by several men; but yet it is not therefore a public one. Accordingly, our legal experts state correctly and explicitly that an act is a public one when the state has deliberated upon it in legitimate assembly; and therefore that action is not public which has been taken by a magistrate or even by the entire populace in a different way as the result of some hasty resolutions. ... With reference to a legitimate assembly, they say that it must be brought together by the sound of a trumpet or bell, or in some other customary fashion. And when the whole state has not been convened, that the deliberations ought still to be directed towards a common action, and that it is not enough to sally forth with the state's equipment and ensigns of war. ${ }^{48}$

Needless to say, in the international realm, such assemblies are absent. Consequently, there is no way of constituting norms or actors of a "globally" public character. The quoted criteria that serve to determine the public character of acts or actors allow them to be recognized as officially representing their particular commonwealth, but, given the context of the argument, this means merely establishing them as subjects of international law in the first place, not stating that they can be identified as internationally public acts or as actors stepping in for the order of international law as a whole. The actors have to qualify for publicness domestically in order to count at all in the international realm, so to speak; ${ }^{49}$ but there they still count as merely private actors. And while there may be norms that are in a certain way binding on sovereigns in the international realm, they have no public authority backing them. There just cannot be such an authority, since for conceptual reasons there can be no legal authority "above" a sovereign head of state. As far as the rules that regulate the "exterior" behaviour of princes are concerned, there can be no public administration of justice; there can be neither judge, nor legislator above the particular sovereign princes. ${ }^{50}$ In a way it does not even make any sense then to speak of laws that bind them:

[T]here cannot be judicial processes between supreme sovereigns (summos Principes) or free peoples unless they themselves consent, since they acknowledge no judge or superior. ...

\footnotetext{
${ }^{48}$ Ibid ch XXI [103].

${ }^{49}$ In a fascinating twist, Gentili applies this argument in justifying interventions that defend mistreated subjects of a tyrannical regime: How can the suffered injuries be made to weigh when a sovereign's subjects have no legal status in international law? Gentili maintains that the subjects first have to be recognized as public actors in the domestic realm and suggests that when a sovereign makes war on his own subjects, he himself is producing the needed empirical evidence for the subjects' own possession of (competing) sovereign power, promoting them to a position in the international realm where they can be legitimate allies and obtain assistance of other sovereigns - whether their cause was just in the first place or not. Cf ibid ch XVI [74-78].

${ }^{50}$ As Panizza, 'Political Theory and Jurisprudence' (n 37) 53 notes, the legal metaphor of 'international law' might boil down to the principle of sovereign equality.
} 
Therefore it was inevitable that the decision between sovereigns should be made by arms. 'War', says Demosthenes, 'is made against those who cannot be controlled by the laws, but judicial decisions are rendered in the case of private citizens'. ${ }^{51}$

Consequently, when it comes to assessing the legal quality of a sovereign's behaviour, only the sovereign him- or herself (or an arbiter authorized by the sovereign) can decide. For example, while natural law might limit the licit causes for war to, among others, fear of aggression, what exactly are sufficient grounds for such fear is up to every sovereign to decide for him- or herself. ${ }^{52}$ The "natural" immediacy of the norms of ius gentium that makes them apply to everyone all over the world at the same time obviates the need for an authority that could help to explain what it means that princes are legally bound by those norms, at least insofar as that would mean providing a way of contesting, adjudicating or sanctioning the infringement of those norms. The international community is the generic community of mankind which can, by the factual overlap of some of its customs, help to identify norms of natural law, but it is not a quasi-political community that can produce norms, interpret and adjudicate them or authorize their enforcement. Strictly speaking, there can be no inter- or even supranational legal process apart from arbitration, for which a consensus of the sovereign princes is required. Consequently war, even though it may be waged for objectively just reasons, is no longer thought of as being part of a quasi-legal process to re-establish justice..$^{53}$

When one admits this relativization of the bindingness of legal imperatives on the sovereigns, the question of the legal character of the international order re-emerges and while legal vocabulary is used throughout all interactions, it is not clear how exactly this order would qualify as a legal order. ${ }^{54}$ At the very least Gentili's global legal order certainly cannot be understood as one of public

\footnotetext{
${ }^{51}$ Gentili, De iure belli libri tres (n 38) lib I, ch III [15].
}

${ }^{52}$ Ibid ch XIV [61-63].

${ }^{53} \mathrm{Ibid}$ ch VI [31-33]. It is possible to read this as an epistemic problem with a pragmatic solution: Objective justice might exist but cannot be known, therefore no judge can be in a position to adjudicate, and therefore a duel is a pragmatic means of decision. Cf Panizza, 'Political Theory and Jurisprudence' (n 37) 18-21. But what makes this epistemic problem different from the one in domestic conflicts, where law and legal proceedings do seem to be a fitting procedure?

${ }^{54}$ Maybe Gentili's provisions defining what war is, what are its admissible causes, how it is to be declared, fought, and terminated are meant to serve as a sort of vocabulary offered to the parties so they can better understand each other and proceed in an orderly way. In this manner they would be binding as standards or language games are: one can only diverge from them at the cost of appearing meaningless to other actors. This does not mean to suggest that such costs are negligible - for eluding these procedures and classifications one might end up being barred from ius gentium altogether or even be considered a 'hostis omnium mortalium', the measures against whom are no longer regulated by law; cf Gentili, De iure belli libri tres (n 38) lib I, ch IV [22f] and lib III, ch XXIII [423]. (On the lack of any legal protection for pirates, rebels etc see also below $n$ 57.) I would maintain, however, that there is an important difference 
law. ${ }^{55}$ It is hard to imagine strict norms resisting arbitrary interpretation by sovereign princes, but if there are any, they are not so much positive norms of that international order, but of natural law. ${ }^{56}$

For Gentili, the source of normative validity of international norms is natural reason revealing that these norms are necessary, not reasonably refutable. Scriptural or historical authorities, the 'great and good men' and even the legal customs of peoples take on an epistemic role in helping to identify these norms. Here Gentili is not even very remote from Vitoria's theory. But even the intentions of the global commonwealth themselves are no more a source of normative validity than the insights of philosophers - they are all just sources of cognizance of those norms. Gentili's insistence on the prevalence of state sovereignty moreover means that the global commonwealth neither disposes of instituted potestas (which is uncontroversial), nor possesses auctoritas: It simply is not a community capable of collective action and of practical rationality at all. Instead it seems to be the mere indication of the extension of natural morality, which is not only unconnected to legal auctoritas or potestas, but a category of an altogether different kind. The global community at the very least does not possess the legal authority that would be necessary to bring the norms of ius gentium to bear against (sovereign) perpetrators on its own initiative or via an organ in a functional sense. $^{57}$

between this type of "sanction" and the sanctions of a public legal order.

${ }^{55}$ This is further corroborated by his replacing the idea of justice as organizing principle with that of a balance of power; ibid ch XIV [64-66]. Cf Panizza, 'Political Theory and Jurisprudence' (n 37) 25; B Straumann, 'The Corpus Iuris as a Source of Law Between Sovereigns in Alberico Gentili's Thought' in Kingsbury/Straumann (eds), Roman Foundations (n 4) 101-123.

${ }^{56} \mathrm{Cf}$ eg Gentili's discussion of the Genoese spoiling the port of Savona in the 1520s, where he is oscillating between 'to me it seems unlawful to destroy harbours' and 'there may perhaps be other reasons which make it lawful to spoil harbours'; Gentili, De iure belli libri tres (n 38) lib III, ch XI [345f].

${ }^{57}$ The same applies to inalienable rights of individuals. For Gentili, no norm of ius gentium can provide a subject of a given potestas with a claim against this potestas or even just a stage on which to articulate such claims. Rebels do not enjoy any status as subjects of ius gentium; rather, like pirates and runaway slaves, their turning away from their authorities strips them of any legal "relationability": "There is also another reason why such men [ie pirates and brigands] do not come under the law of war; namely, because that law is derived from the law of nations, and malefactors do not enjoy the privileges of a law to which they are foes'; 'To raise the former questions [what can be or has usually been done with such men] is to argue on the basis of law, that is to say, the tie by which we are bound to our fellow men; but we are not bound to brigands by any such tie.' Ibid lib I, ch IV [22f]. Compare this to the absolute impermissibility of putting any person outside of all law in Vitoria's discussion of foreigners acquiring citizenship; OAI q 3, art $1, \S 5$ [281]. (See also on the absolute value of fundamental rights above, text to $\mathrm{nn} 28 \mathrm{f}$.) It is as if for Vitoria, first of all, all human beings have been subjects of ius gentium and then as it were have constituted commonwealths and thus added to or eventually subtracted from their rights, but never so far as to fall out of the legal relation as such, while for Gentili, only commonwealths are subjects of ius gentium and individual persons matter only insofar as they are "connected" to some commonwealth. For a brief hint at how this - at least as far as Vitoria is concerned - relates to 


\section{Conclusion}

We have seen that both Francisco de Vitoria and Alberico Gentili in their elaboration of ius gentium can be understood as starting from the classical definition, which had defined it as constituted by natural reason in all of mankind. Classically, this had meant both its normative foundation and the source of its factual existence in the world. But what it means for a law to be legally binding had not been a very prominent question of the classical discussion, and here both authors offer their solutions.

But one approach leaves the definition untouched and adds the notion of political sovereignty. Then, according to the definition, all of mankind "knows" that everyone is bound by certain laws the identification of which is realized by various epistemic functions that often themselves have a "transnational" dimension (history, philosophy, comparative legal analysis). These laws weigh in all social circumstances, be they a "state of nature" or the "civitas", and thus they can claim adherence also within and past the boundaries of sovereign states. The instruments of adjudication and enforcement, however, are constituted neither by the reasonableness nor by the universal applicability of the respective norms, but by the rather independent notion of (domestically constituted) sovereignty. To the extent that the concept of sovereignty is linked to strong notions of factual legislation or unified administration/gubernatio, there are of course serious doubts about the conceptual possibility of a global sovereign. This leads to the situation that, because of its supposedly global recognition, law may serve as a medium of communication and of coordination in the interactions between sovereigns, but surely not in the way of public norms cogently regulating their behaviour. Internally, each sovereign and each commonwealth may describe his or its actions as being justified or bound by norms of ius gentium (and even be perfectly honest in doing so). But from the point of view of actors outside of that particular commonwealth, there is no reason to have any confidence in the regulating capacities of those norms, let alone any means to actively control or enforce them. There is just no such thing as supranational legislation, adjudication or enforcement of norms and this is where the story ends. While there is supranational law after all, it is one of natural reason, a natural law, backed and recognized by a moral community. The global legal order is not a commonwealth, built around law as a form of public practice and around a common good. It has no autonomous law-making power: In their normative foundation, its norms are analogous to natural law, given rather than positively made; but in their practice these norms are analogous to private law, depending on the private authority of consenting

Hannah Arendt's discussion of a "right to have rights” cf Wagner, 'Verhältnis von Völkerrecht und Rechtsbegriff' (n 29). 
subjects. $^{58}$

The other approach gives the notion of reasonabless of laws a social or communal character and the laws themselves an institutional one. Reasonableness with regards to laws implies an orientation towards a common good and thus a reference to a legal-political community as a whole, and reasonable laws imply the authority to coerce those who do not consent for the better of the whole community. And this authority is necessarily connected to the practical reason of the community the community is not just the object, but must also be the subject of legislation. In this way, the ius gentium is connected in a very different way to the global community of mankind: The universal recognition of ius gentium no longer concerns only its cognizance or the extension of its use, but feeds back into its normative validity, and the communitas totius orbis is both the horizon and the source of ius gentium. The idea that all human beings originally and ideally have been constituted as subjects of ius gentium does not mean that they could not later have decided to constitute a plurality of commonwealths, such as those that presently figure as main entities in international law. But it means that the claims of particular commonwealths remain subordinate to the global legal community as a whole (and to some claims that individuals still can make). Unlike Gentili, Grotius and later Pufendorf, Vitoria insists that law enforcement, when it passes the crucial threshold of punishment, requires public, not merely private authority. But unlike Hobbes, he maintains that there is such an authority on the global level, that it is not self-contradictory and that it is necessarily presupposed by attempts to justify the present international landscape. ${ }^{59}$

For a republican international legal order, the "reason" of all human beings is not only a natural capacity, but, taking into account their social condition, can be thought to constitute an auctoritas in the legal sense. When the (presumed) reasonable intention of the global community is the more proximate normative foundation of ius gentium, then the problem of how to recognize when such an intention has formed still remains, and again various epistemic functions may be mobilized to that end. Similarly, the problem of identification and establishment of adequate institutional structures is not at all addressed. But once a legislating intention of the global community is identified, and once mechanisms of its assertion and enforcement are in place, we may draw on arguments presented in

${ }^{58}$ Thus I am still not convinced that when according to this approach 'the idea of the global respublica performs ... [a] fundamental function [and] constitutes the foundation of the so-called "international community" and the primary source of legitimation of the ius gentium bellicum' (Panizza, 'Political Theory and Jurisprudence' (n 37) 50), it has any legal effect.

${ }^{59}$ For a comparison of the models of Grotius, Pufendorf, and Hobbes, to which Gentili's and Vitoria's approaches remain to be contrasted, cf B Kingsbury and B Straumann, 'State of Nature versus Commercial Sociability as the Basis of International Law. Reflections on the Roman Foundations and Current Interpretations of the International Political and Legal Thought of Grotius, Hobbes, and Pufendorf' in S Besson and $\mathrm{J}$ Tasioulas (eds), The Philosophy of International Law (OUP, Oxford 2010) 33-52. 
these portraits of Vitoria and Gentili to understand the normative grounds and the particular character of the authority that such norms and their enforcement can claim. 